\title{
Analysis on the Current Situation and Countermeasures of Research-Based Teaching in Finance Major in Finance and Economics Universities
}

\author{
WEI Hongliang \\ School of Finance \\ Nanjing University of Finance \& Economics \\ Nanjing City, China. 210023 \\ Hongliangwei80@163.com
}

\author{
MAO Zesheng \\ School of Finance \\ Nanjing University of Finance \& Economics \\ Nanjing City, China. 210023
}

\author{
WANG Hui \\ School of Finance \\ Nanjing University of Finance \& Economics \\ Nanjing City, China. 210023
}

\begin{abstract}
Research-based te aching is a teaching model that is currently widely respected both at home and abroad. In order to cultivate the financial talents needed by the newera, the financial colleges and universities in our country have carried out research-based teaching one after another, but the current situation is not satisfactory. Problems such as the shortage of teaching resources, the backward concepts of teachers and students and the lack of curriculum. In order to solve these problems, it is necessary to take measures such as the rational use of funds, changing the concept of teachers and students, improving the curriculum and evaluation system so as to promote the development of research-based te aching.
\end{abstract}

Keywords-finance major, research-based teaching, current situation, countermeasures

\section{INTRODUCTION}

Research-based teaching, centering on problems, is a kind of organizational form of teaching characterized by 'the emphasis on the process, application, experience and participation of all" in which students actively acquire and apply knowledge and solve problems in the process of research under the guidance of teachers, which is now a universallyaccepted teaching mode at home and abroad. In contrast to the traditional teaching mode, research-based teaching, centering on "problems", attaches much more importance to stimulating students' creativity and their ability to propose and solve

Fund Project: periodical achievement on the key project of academic degrees \& graduate education of "Innovative Cultivation for Graduates Majoring in Economics \& Management" in Nanjing University of Finance \& Economics in 2016. Project Grant No.: XW16001; Periodical achievement on "Category-A Project of the Phase 1 in Brand Majors Construction of Jiangsu Institutions of Higher Learning" in Education Department of Jiangsu. Project Grant No.: PPZY2015A001; Breeding project of teaching results at college level of "Exploration and Practice on Talents Cultivation Mode in Finance and Economics Colleges and Universities by Combining with Professional Qualifications--A Case Study of CFA" in Nanjing University of Finance \& Economics in 2016, Project Grant No.: JXCGPY201604. problems in the teaching process, breaks through the closed, one-way transmission teaching mode which takes classrooms as its environment, centers on teachers, uses paper materials as its tool and makes students discover, think and solve problems independently so that theoretical knowledge can be used in practice and mastered, thus ultimately cultivating students' abilities on study, research and innovation.

The philosophy of research-based teaching has a long history. As early as the Spring and Autumn Period and the Warring States Period, Confucius, the great thinker and educator in ancient China, proposed similar idea that teaching is the process involving learning, asking and thinking. For instance, he advocated "asking about everything", emphasized the combination of learning and asking and held that students should take the initiative to learn and research for their own problems. Meanwhile, he also pointed out that " learning without thought is labor lost; thought without learning is perilous", which means that learning is as important as thinking and we should combine learning with thinking to avoid reading without thinking and thinking without studying. ${ }^{[1]}$ All of these are the beginning of research-based teaching. Modern researchbased teaching stems from western countries in the 18th century. At that time, Rousseau, French great enlightenment thinker, educator and writer, believed that people are born with curiosity and endowed with the desire to explore the unknown and teachers should raise questions by setting situations and provide students with freer and more active independent learning environment. In the 19th century, German educator Alexander von Humboldt maintained that "research" should be a function of universities. Such philosophy has a far-reaching influence on the development of universities later. In the same era, American educator John Dewey proved the necessity of scientific inquiry in his book Democracy and Education: An Introduction to the Philosophy of Education and put forward 
five steps to teach centering on problems, thus forming the "problem-based teaching method".[2] In the beginning of 20th century, according to the theory of John Dewey, William Heard Kilpatrick proposed "project method of teaching", which aims to stimulate the potential of children and make them study by themselves. In 1960s, American educator Jerome Bruner and Joseph Schwab greatly promoted the reform of curriculum and teaching and demonstrated the rationality of "discovery learning" and "inquiry-based learning". Their teaching philosophies still have positive instructive function to current practice of research-based teaching.[1] After 1980s, America firstly began educational reform and paid attention to the cultivation of students' ability on inquiry and practice and sense of social responsibility. After that, since 1990s the transformation of learning style was considered as an important content for the curriculum reform in many countries around the world. Asian countries such as Singapore and Japan invariably emphasized the cultivation of students' creative spirit and ability of practice and set up the curricula which are similar to the "research-based teaching" of China.

Through so many years of development, the theory of research-based teaching is well-established and its philosophy continues to mature. Chinese scholars have done a lot of research on it. For example, Zhao Hong (2006) summarized several typical research-based teaching modes, analyzed the similarity among them and outlined the difficulties of researchbased teaching carried out in our country which raise new demands on teachers' case design and evaluation level, the ability of students to study actively, etc.[2] Liu Zanying et al (2007) proposed that it should strengthen the organic combination of teaching and research and improve research management system for undergraduates and related motivation mechanism for teachers in order to promote the implementation of research-based teaching in our country by analyzing research-based teaching in America.[3] Yao Limin and Kang Wen (2009) analyzed the current situation of research-based teaching in our country through questionnaire. They believed that the research-based teaching carried out in China is not satisfying, the reasons of which are related to both subjective factor of teachers and students in cognition and objective factor of insufficient hardware condition.[4] Qu Bo (2011) analyzed the ideological basis of research-based teaching, summarized its characteristics of process, experience and synthesis, and further explored the basic approach to carry out research-based teaching in courses including the construction of design plan of research-based teaching, the establishment of research-based teaching resources and the change of teachers' role.[7] $\mathrm{Wu}$ Ruilin (2013) creatively integrated psychological contents with research-based teaching from the perspective of psychology, analyzed the relationship between research-based teaching and the cultivation of innovation quality and put forward suggestions for promoting the development of research-based teaching: choosing appropriate research projects, creating free environment for research exchange and providing positive feedback for students.[6] Ren Lichan (2015) surveyed five institutions of higher learning of Hunan province, analyzed the reasons of slow development of current research-based teaching from the aspects of teachers, students and colleges and put forward some related suggestion for improvement.[16] Qi Ning (2016) analyzed the current problems in promoting research-based teaching in colleges and universities, such as the limitation of traditional teaching mode, limited cognition of teachers on research-based teaching, students' passive learning mode formed since very young, etc. and put forward relevant solutions including setting the goal to cultivate innovationoriented talents, establishing the platform of talents cultivation for the integration of interdisciplinary from undergraduate to postgraduate, etc.[15]

Although many Chinese scholars have made lots of researches on this aspect, unanimously emphasize the importance of research-based teaching and maintain that it should vigorously promote research-based teaching, the development and implementation of research-based teaching in practice are still beyond optimistic. In particular, comparing with other majors, the application of research-based teaching in finance major in finance and economics colleges and universities lags far behind. In today's society, the pace of life speeds up, the innovation of science and technology accelerates, and the speed in updating information is even faster than ever before. Additionally, world economy is still in the postfinancial era, political and economic environment are far from quite safe, and China is in the painful period of deepening reform and adjusting industrial structure. Against this background, the state and society draw higher standard in financial talents, requiring more comprehensive innovative excellent graduates with practical skills. Therefore, there is a long way to go for finance and economics colleges and universities to carry out research-based teaching in finance major.

\section{CURRENT SITUATION AND REASONS FOR FINANCE AND \\ ECONOMICS COLLEGES AND UNIVERSITIES TO CARRY OUT RESEARCH-BASED TEACHING IN FINANCE MAJOR}

As early as 1980s, Tsinghua University, Nanjing University and other institutions of higher learning as a vanguard, began a preliminary exploration on "research-based teaching".[5] After 2000, the Ministry of Education formally proposed in documents to promote "research-based teaching" and "research-based learning" successively. And many finance and economics colleges and universities responded positively and vigorously promoted teaching reform, integrated researchbased teaching into daily teaching work.

However, according to sample investigation, $42.7 \%$ students and $54.5 \%$ teachers hold that it is not so good to carry out research-based teaching in each institutions of higher learning at present, $36 \%$ students and $28.5 \%$ teachers think it is worse and $5.8 \%$ students and $2.6 \%$ teachers believe there is little research-based teaching in their colleges.[8] Besides, according to another investigation, 91\% students recognize and accept research-based teaching and $75.3 \%$ students believe that it should carry out such teaching mode in professional courses.[9] It is obvious that students themselves accept such research-based teaching but current situation cannot meet the need of them and cannot motivate enthusiasm of faculty and students.

Compared with other majors, it is even worse to carry out research-based teaching in finance major in finance and economics colleges and universities. On the one hand, there is 
a certain gap between comprehensive colleges and universities and finance and economics ones with relatively late time to found colleges and short time to develop colleges. On the other hand, as a very important practical course, students of science and engineering have wider breadth and depth than that of finance major in research-based teaching. Because compared with science and engineering, the finance major has a short history in our country, the degree of professional improvement is relatively low, capital investment and resources are relatively small, which are constraining the development of finance research teaching.

Now that we began the exploration on "research-based teaching" as early as1980s, why its development today is not as good as we imagine? The main reasons are as follows:

\section{A. High conversion cost for deep-rooted traditional teaching mode}

As we all know, traditional teaching mode in which teachers are in charge of imparting knowledge and students passively accept these knowledge is currently mainstream teaching mode, regardless of junior school, high school or college. Such cramming teaching mode is just to impart knowledge.[10] And what students should do is to understand the contents of textbooks and pass examinations. Obviously, such traditional teaching mode is very efficient but students are lack of innovative thinking and ability to find and solve problems independently, which is hard to meet the need of new era. It is not uncommon in finance major, or even worse for the lack of practical courses.

Although all circles of society know the importance of teaching reform very well, the dominant role of traditional teaching not only causes teachers to spend a great deal of effort and time to change their teaching mode, but also makes students spend lots of time to adjust to new research-based teaching and is very costly to change teaching mode, which are the reasons for the slow development of research-based teaching and the difficulty to shake the deep-rooted foundation of traditional teaching mode by only reforming on some curricula.

\section{B. Insufficient funds for research-based teaching and short of teaching resources}

In China, institutions of higher learning belong to public institution, the funds of which mainly come from government. Due to the limitation of disciplines and majors, the amount of fund of finance and economics colleges and universities obtained from government is relatively small, which makes the infrastructure of colleges fall behind and teaching resources cannot meet the needs of research teaching. For finance major, its teaching has distinct characteristics of times, applicability and technology. Financial laboratory keeping closely up with the times plays a decisive role in the research-based teaching in finance major. However, to build a financial laboratory that meets the needs of teaching is not only to require various hardware facilities such as computers, printers, etc., but also plenty of software such as simulation trading system of bank, security trading, and exchange market, etc. All of these require plenty of funds. We found by investigation that only $28.43 \%$ colleges and universities believe that their teaching funds are "relatively sufficient", $48.46 \%$ believe that their teaching funds can only meet the need of regular expenses and $24.11 \%$ believe that their teaching funds are "seriously inadequate" in the 21 finance and economics colleges under investigation.

In addition, such problems as inappropriate and chaotic expenditure structure also exist in the use of expenditure of finance and economics colleges and universities, which further causes the efficiency decline in the use of teaching funds. Meanwhile, nowadays many institutions of higher learning increase enrollment while the increase pace of funds is not match with that of students' number, which also leads to further reduction of teaching resources on each student on average. All of these are not conducive to the efficient development of research-based teaching.

\section{Lack of innovative curricula and old-fashioned teaching contents}

At present, after the "211/985 project" in our institutions of higher learning, another key national strategy "the construction of world-class universities and disciplines" is also launched in order to promote the comprehensive strength and international competitiveness of Chinese higher education. Additionally, with further deepening of Chinese opening to the outside world, China's position in the world financial system is getting higher and higher and the inclusion of RMB in SDR marks the integration of Chinese economy into global financial system. Such background and pattern of times require our students to have broader vision, advanced ideas and first-class quality, thus connecting with the international perfectly. In order to achieve such goal, from the perspective of curriculum, we need to put curricula with epoch character, innovation and practice into optional lists for students such as financial derivatives, risk prevention of foreign exchange, etc. to cultivate various innovative, applied and comprehensive talents with initiative spirit and practical ability.

However, at present, there are few practical curricula with foresight and innovation in many finance and economic colleges and universities and few options available to students. Most of teachings are still occupied by traditional classic theories. Even with innovative practical curriculum, its objectives are hard to be achieved due to the deficiency in software and hardware. The objectives are only can be achieved in theoretical teaching but hard to be carried out in practice.[11] In the meantime, as for those basic courses in the finance major such as western economics, investment, banking, etc., some teachers less connect the contents with today's changing time and only teach the contents of textbooks that are relatively outdated. They neither open the door facing to the development of contemporary finance for students nor stimulate students' ability on mastering and solving problems and original innovative ability. As the sublimation part of research-based teaching, the failure of innovative curricula and teaching contents to keep pace with times must cause the slow development of research-based teaching. 


\section{Teachers pay insufficient attention to researching teaching and lack innovative thinking}

In contrast to traditional teaching, research-based teaching unifies research, innovation and practice, which poses new challenge for teachers. Compared with other disciplines, finance major has close relation with financial practical departments. But financial industry is changing rapidly and constantly, thus presenting higher demands for teachers of finance major. They not only have to get familiar with the contents of textbooks and answer students' questions with their thorough knowledge, but also keep up with the times and bear the frontier of contemporary financial development in mind to broaden students' international horizon and update teaching methods and contents constantly. They not only should maintain the seriousness of classrooms, but also activate the atmosphere of classrooms to create a kind of environment suitable to research-based teaching. They not only should study and teach rigorously, but also have innovative and active thinking. In addition, teachers should change self-positioning and the image of "teachers being the authority" in traditional teaching and transfer from previous dominant role into the supporting role in order to promote students to study independently, stimulate their interests, guide them to find problems and cultivate their ability on solving problems.[12]

However, due to long history of the traditional teaching mode in China, teachers have formed a great deal of teaching style and are accustomed to taking the syllabus in the classroom. Although they try to add some practical operation, they are still rooted in traditional teaching atmospheres with limited effect. More importantly, teachers not only need to prepare each lesson and design teaching method very carefully, but also continue to care and guide students to study independently after classes when they conduct research-based teaching, which, to great extent, increases the work amount of teachers. Thus, teachers take less initiative to conduct researchbased teaching and pay little attention to it with each passing day. Furthermore, many teachers works in institutions of higher learning as soon as they graduate from colleges, which make them lack of work and practical experience. While mentors from outside colleges may be lack of professional knowledge. All of these restrict to stimulate the vitality of teaching and innovation and are not conducive to the development of research-based teaching.

\section{E. Students'long-term passive study and low self-motivated learning enthusiasm}

Teaching is a two-way process in which teachers impart knowledge and students study. Students are also responsible for the poor current situation of research-based teaching. In China, due to the existence of college entrance examination system, students are gradually accustomed to the passive learning mode. Therefore, they are lack of independent thinking and the enthusiasm to study on their own. And in most cases, they just accept what teachers impart and aim to obtain high rank and scores in examinations, which will causes such situation as "pays no attention to what is going on beyond their study and bury themselves in the classics". Under such circumstance, students who lack the awareness to study independently are hard to adapt to such two-way research-based learning. In turn, the teaching effect is also not up to expectations. Besides consuming their energy, teachers also spend more time to study and research in their free time and increase the cost of study and the time to adapt to, which makes students resist researchbased teaching and is not conducive to the implementation and effect of research-based teaching.

\section{F. The emphasis on the result instead of the process in existing teaching evaluation system is not conducive to carry out research-based teaching}

The evaluation system of teachers' teaching performance is a system which evaluates the teaching quality of teachers. It is an important part in the evaluation of the performance of public departments, and also acts as an effective and powerful tool in teacher management. At present, such system arouses lots of controversies.

On the one hand, based on traditional teaching mode, current evaluation system of teachers' teaching performance focuses on the result instead of the process. It emphasizes the results of teaching and academic research of teachers and underlines such mandatory indexes as excellent rate of examinations and publication of papers while ignores the teaching process of teachers and learning process of students. Such situation goes against the objectives and original intention of research-based teaching. Research-based teaching pays much more attention to the process and attaches great important to the cultivation of students' ability on learning initiative, practice, finding and solving problems in the process. It is obvious that many achievements of research-based teaching cannot be reflected in performance evaluation even teachers emphasize research-based teaching, which does little to help the development of teachers' career. While it is more beneficial and easier for teachers to directly adapt traditional teaching method in their performance evaluation. Undoubtedly, it will affect teachers' enthusiasm to carry out research teaching.

On the other hand, "research determinism" prevails gradually in institutions of higher learning, with no exception of finance and economics colleges and universities. According to investigation, it is found that the amount of time invested by teachers of finance and economics colleges and universities has increased from $20.8 \%$ to $33.4 \%$ over the past decade. Although the increased amount of time in research by teachers is beneficial to the improvement of teachers' theoretical level and teaching quality, decreased effort in teaching will inevitably lead to a relatively decrease in aspects of teaching contents, method and the way to communicate with students, thus being not conducive to carry out research-based teaching with limited effect.

III. THE RELEVANT SUGGESTIONS FOR THE IMPROVEMENT OF RESEARCH-BASED TEACHING IN FINANCE MAJOR IN FINANCE AND ECONOMICS COLLEGES AND UNIVERSITIES

Corresponding measures can be taken to solve the problems mentioned above and promote the development of researchbased teaching in finance major in finance and economics colleges and universities. 


\section{A. Use fund properly to avoid the waste of resources}

As analyzed above, the relative small amount of funds granted by government for many finance and economics colleges is hardly meet the needs of the construction of infrastructure and the preparation of teaching resources, which thus requires finance and economics colleges and universities to "increase income and reduce expenditure". First of all, from the perspective of "reduce expenditure", it has the room for adjustment since there is improper use of funds in finance and economics colleges. Therefore, finance and economics colleges and universities should have overall plans to prioritize the scheduled things and take teaching into consideration firstly, which, to some extent, can guarantee the allocation of teaching funds. After all, with teaching guaranteed, the future of colleges will be guaranteed. In addition, it should reduce unnecessary waste in regular expenses and try to "use material where it is needed most". In finance major, we should take these policies into effect to avoid deviation of correct policies from superior level in practice. Secondly, from the perspective of "increase income", government grant is the result of overall plan in the whole province or even the whole nation, which is difficult for colleges to intervene. Although it is possible to ask for more funds from government departments concerned, it is not feasible. Therefore, finance and economic colleges and universities should find a new path, try to build partnership with some financial enterprises to draw on each other's advantages and obtain some useful teaching resources from financial enterprises such as teaching cases, students' in-depth internship, etc. What's more, it should make full use of alumni resources at school and college level and encourage wellknown alumni to invest in the establishment of special funds for research teaching.

\section{B. Change the concept and self-positioning of teachers and students}

The mode and philosophy of traditional teaching have a long history which has a huge influence on teachers and students. In order to promote the development of researchbased teaching in finance major in finance and economics colleges and universities, it should change the concept of teachers and students.

Teachers are the key to carry out research-based teaching and the primary goal to change. Firstly, teachers should endeavor to transfer themselves from previous "dominant role" into now "supporting role", do not teach according to the textbooks anymore in their daily teaching but guide students to study independently.[7] Furthermore, they should transfer the teaching process into not only a learning process for students to acquire knowledge but also a process in which they promote academic research simultaneously. Secondly, finance and economics colleges and universities should strengthen teachers' training in research-based teaching to make them know research-based teaching and advanced teaching methods. In finance major, teachers should be encouraged to attend symposium and exchange teaching experiences in order to promote the implementation of research-based teaching in the professional fields. Lastly, as above mentioned, it will to great extent increase the amount of working time to carry out research-based teaching. Therefore, colleges and universities should establish a motivation mechanism concerning researchbased teaching to increase teachers' enthusiasm to carry out research-based teaching and realize sound development.

In research-based teaching, students should transfer from previous one-way knowledge receiver into two-way independent learner.[13] Perhaps, students do not adapt to such change of identity at the very beginning. Finance and economics colleges and universities should increase publicity, stimulate students' interest in research-based teaching and change their concept in an unnoticed manner with the help of medium such as WeChat, website, etc. What's more, teachers should proceed in an orderly way and do not push such teaching to a point where students lose their interest in the very beginning. For the major of finance, teachers can increase case study on contemporary financial hot topics in a progressive way in class and provide some interesting and timely financial information for students after class. Lastly, as for the assessment mechanism on students' performance, it can gradually change such traditional approach as "one examination determines the rest of your lifetime",[15] pay more attention to students' performance in their daily study, create more opportunities for students to analyze cases, state their opinions on financial hot issues and write literature review, combine daily observation with traditional examination and evaluate their academic performance from multiple dimensions.[14]

\section{Optimizing courses and innovating teaching contents}

It is not uncommon for Chinese finance and economics colleges and universities to be short of courses. The number of courses in domestic leading institution of higher learning such as Tsinghua University and Beijing University totals about 3000 and this figure decreases to about 1500 to 2000 in general finance and economics colleges. While American similar institutions of higher learning can basically offer over one course for each student, which means that colleges with 7000 students have about 8000 courses and colleges with 10,000 students may have 12,000 courses.

Therefore, in order to further meet the learning need of students in finance and economics colleges and universities, these colleges should firstly increase courses and continuously update courses in accordance with new trend of economic development at home and abroad to guarantee courses and students to keep pace with the times.[6] For example, finance major can open such courses as contemporary financial hot issues. Secondly, we should further refine existing courses, enrich courses lists, pinpoint students' interests and stimulate their learning interests to make them have a deeper and clearer understanding on courses where practicable. Furthermore, finance and economics colleges and universities should improve the mechanism of courses, abandon previous majors and find talents mode of teaching. Because under such mode, completely suitable teaching talents are hard to employ and the setup and teaching of courses are bound to have various problems. Thus, we can learn from American institutions of higher learning. In this regard, we can learn from the practice of the United States colleges and universities: first set the curriculum according to hot spots and needs of the community, and then set up new major after the formation of a matching 
curriculum system. This model will obviously make up for the shortage of domestic curriculum, and help to ensure the quality of curriculum and teaching. Lastly, finance and economics colleges and universities should strengthen the cross-class exchanges among different courses, because talents cultivated by finance and economics colleges and universities should be comprehensive one instead of the nerd just knowing economics and finance. Therefore, it should strengthen resources sharing among different departments and schools or even select courses in different colleges in order to make full use of the advantages of different majors and colleges, combine economic knowledge with other knowledge and improve students' comprehensive quality in an all-round manner.

With regard to micro-teaching contents, in order to achieve the goal of research-based teaching, finance and economics colleges and universities should require their teachers to dynamically adjust and update teaching contents in accordance with social hot issues and the frontier of theoretical development, guide students to pay close attention to social issues and frontier of disciplines and stimulate their interest in research and exploration, which also urges teachers to constantly improve their research in the depth and width of teaching. In addition, teachers should weed through the old to bring for the new and be willing to try various teaching methods. Of course, teachers can gain teaching inspiration and ideas by discussing with students to develop research-based teaching well, cultivate students' cooperative awareness and improve their ability on finding and solving problems.

\section{Improvement of motivation mechanism and evaluation system of performance}

Research-based teaching sets a higher standard for teachers' teaching, but with diversified missions of higher education today, the motivation mechanism for teachers in finance and economics colleges and universities is getting fewer and fewer and it is very common to "emphasize on research and ignore teaching"..[16] Therefore, finance and economics colleges and universities should improve motivation mechanism and guide teachers to spend more time in teaching and actively develop research-based teaching. Those teachers who have done well in research-based teaching should be provided with spirit and material reward to make them get tangible material rewards and economic returns when they are immersed in the joy of having students all over the world.

In addition, finance and economics colleges and universities should improve the evaluation system of performance in time as needed. Therefore, on the one hand, teaching effectiveness of research-based teaching should be included in the evaluation system as extra points, and guidance and supervision should be strengthened. As for the finance major, performance of practical operation concerning finance such as dealing in securities and foreign exchange transactions which can be regarded as one of factors to evaluate teachers can be included into evaluation system of teaching performance. On the other hand, it should attach importance to students' evaluation on teachers and accept the necessity and rationality of it. Because students are the direct object to feel the effect of teaching and teachers' attitude. Their feelings are unique and important. Furthermore, students' evaluation on teachers has economic and sustainable advantages. Therefore, the feasible, reliable and scientific evaluation on teachers by students can be completely guaranteed with appropriate evaluation approach. Thus, only by perfecting evaluation system of teaching quality, aiming at students' healthy growth and building correct, scientific, efficient, simple and clear evaluation system can students be stimulated to work hard and grow healthily.

\section{REFERENCES}

[1] Shi Manli, Yao Limin, Kang Wen, Jiang Jiaqiong. On the Development of Research-based Teaching Thought [J].University Education Science, 2008(06):35-41.

[2] Zhao Hong. Study-based Teaching and College Teaching Methods Reform[J]. Journal of Higher Education, 2006(02):71-75.

[3] Liu Zanying, Wang Lan, Zhu Jingran, Zhang Yu, Zhang Yanhong. Enlightenment and Experience of the Research Teaching of the Higher Education Abroad [J]. Journal of Hebei University of Science and Technology(Social Sciences), 2007(01):68-75.

[4] Yao Limin, Kang Wen. Analysis on Current Situation and Reasons of Research-Based Teaching in Colleges [J]. China University Teaching, 2009(01):19-23.

[5] He Yunfeng. Study on Development Path and Construction of Mode of "Research-Based Teaching" in Colleges[J]. China University Teaching, 2009(10):81-83.

[6] Wu Ruilin, Wang Jianzhong. Research-Based Teaching and the Cultivation of Innovative Ability for Graduates[J]. Academic Degrees \& Graduate Education, 2013(03):10-15.

[7] Qu Bo, Cheng Zhe, Ma Zhong. Research and Practice of Teaching Mode for Undergraduate Education Based on Independent Study and Research-Based Teaching [J]. China Higher Education Research, 2011(04):85-87.

[8] She Yuanfu, Wang Qingren. Constructing Evaluation Systme of Research-Oriented Teaching in Higher Institutions[J]. Research in Higher Education of Engineering, 2011(06):111-115.

[9] Cao Jinhua. Practical Exploration and Thought on Research-Based Teaching in Institutions of Higher Learning--Reflection on The Status Quo of Research Teaching in Universities: Investigation and Reflection[J]. Journal of Yangzhou University(Higher Education Study Edition), 2012(S1):8-12.

[10] Bie Dunrong. Research-Based Teaching and its Requirement for Implementation[J]. China University Teaching,2012(08):10-12.

[11] Gu Jiayang, Liu Weimin. Some Reflection on the Researches in "Research-Oriented Teaching" in Universities[J].Journal of Yangzhou University(Higher Education Study Edition), 2012(05):78-82.

[12] Xia Jinwen, Cheng Xiaoqiao. Theoretical Connotation and Practical Requirement of Research-Based Teaching $[\mathrm{J}]$. China University Teaching, 2009(12):25-28.

[13] Liu Yanli, Zhang Yumei. The Construction of Research-Based Teaching in Colleges and Universities[J]. Journal of Hebei University of Engineering(Social Science Edition), 2013(04):105-107.

[14] Wang Junsheng. Problems and Solving Strategies on the Reform of Research-Based Teaching in Institutions of Higher Learning[J]. Higher Agricultural Education, 2013(11):73-76.

[15] Qi Ning. Problems and Countermeasures in Research-Based Teaching in Current Institutions of Higher Learning [J]. Education and Vocation, 2016(16).

[16] Ren Lichan. Theoretical Reflection on the Reform of Research-Based Teaching in Institutions of Higher Learning in China [J]. Education Review, 2015(12):10-13 